\title{
Continuous Monitoring of Enzymatic Whey Protein Hydrolysis. Correlation of Base Consumption with Soluble Nitrogen Content
}

\author{
Antoine Margot, ${ }^{a}$ Erwin Flaschel ${ }^{b}$ \& Albert Renken ${ }^{a}$ \\ ${ }^{a}$ Institut de génie chimique, Ecole Polytechnique Fédérale de Lausanne, CH-1015 Lausanne, Switzerland \\ ${ }^{b}$ Technische Fakultät, Universität Bielefeld, PO Box 1001 31, D-33501 Biefeld 1, Germany
}

(Received 23 November 1992; revised version received and accepted 18 March 1993)

The optimization of enzymatic protein hydrolysis often represents a tedious task due to complicated analytical methods. The simplest system of continuous analysis consists of monitoring the base consumption during a pH-controlled reactor operation. However, there are other criteria commonly used for characterizing the extent of protein hydrolysis, comprising the degree of hydrolysis (DH) and the SN-TCA index, that is the fraction of nitrogen soluble in trichloroacetic acid under well-defined conditions. Taking the SN-TCA index, expressed in terms of the so-called fraction of non-protein nitrogen NPN, as an example, it is shown that these criteria may be correlated with base consumption. The advantages and limitations of this method are discussed.

\section{NOTATION}

$a_{i} \quad$ Regression coefficients

$c_{B} \quad$ Concentration of a strong base used for pH-control (mol litre ${ }^{-1}$ )

$c_{\overline{\mathrm{C}}}^{-} \quad$ Concentration of terminal carboxylate ions (mol litre ${ }^{-1}$ )

$c_{\mathrm{C}}^{\mathrm{n}} \quad$ Concentration of terminal protonated carboxyl groups ( $m o l$ litre ${ }^{-1}$ )

$c_{\mathrm{H}} \quad$ Concentration of hydronium ions (mol litre $^{-1}$ )

$c_{\mathrm{N}}^{+} \quad$ Concentration of terminal protonated amino groups ( $\mathrm{mol}$ litre $^{-1}$ )

$c_{\mathrm{N}}^{\mathrm{n}} \quad$ Concentration of terminal deprotonated amino groups ( $\mathrm{mol} \mathrm{litre}^{-1}$ ) $c_{\mathrm{pb}}^{0} \quad$ Initial concentration of peptide bonds ( $\mathrm{mol}$ litre $^{-1}$ )

DH Degree of hydrolysis (\%)

$E_{\mathrm{o}} \quad$ Enzyme (protease) concentration (g litre $^{-1}$ )

$K_{\mathrm{a}}^{\mathrm{C}}$ Acid dissociation constant of terminal carboxyl groups ( $m o l$ litre $^{-1}$ )

$K_{\alpha}^{\mathrm{N}}$ Acid dissociation constant of terminal amino groups ( $\mathrm{mol}$ litre $^{-1}$ )

$M_{\mathrm{pb}}$ Apparent mean molar mass associated with a peptide bond $\left(\mathrm{g} \mathrm{mol}^{-1}\right)$

$m_{\mathrm{P}}^{\mathrm{o}} \quad$ Initial protein mass in the reactor $(\mathrm{g})$

$n_{\mathrm{B}} \quad$ Number of moles of strong base added for $\mathrm{pH}$-control (mol)

$n_{\mathrm{Bm}} \quad$ Number of moles of strong base added per unit mass of protein present $\left(\mu \mathrm{mol} \mathrm{g}^{-1}\right)$

Corresponding author: Erwin Flaschel. Tel: 49521106 5301; Fax: 495211066328. $n_{\mathrm{pb}}^{\mathrm{o}} \quad$ Initial number of moles of peptide bonds (mol) 
NPN Fraction of non-protein nitrogen or of soluble protein $(\%)$

$\mathbf{N P N}_{\mathrm{o}}$ Initial NPN (\%)

$\mathrm{pH}$ Acidity exponent

$\mathrm{p} K_{\mathrm{a}}^{\mathrm{C}}$ Acid dissociation exponent of terminal carboxyl groups

$\mathrm{p} K_{\mathrm{a}}^{\mathrm{N}}$ Acid dissociation exponent of terminal amino groups

$S_{\mathrm{o}} \quad$ Protein concentration $(\% \mathrm{w} / \mathrm{w})$

$T_{c} \quad$ Reaction temperature $\left({ }^{\circ} \mathrm{C}\right)$

$V_{\mathrm{B}} \quad$ Volume of strong base added (litre)

$V_{\mathrm{R}} \quad$ Reactor volume (litre)

$x_{\mathrm{B}} \quad$ Number of moles of strong base added per number of moles of peptide bonds hydrolysed or titratable portion of peptide bonds hydrolysed

$x_{C}^{\mathrm{n}} \quad$ Molar fraction of terminal protonated carboxyl groups

$x_{\mathrm{N}}^{\mathrm{n}} \quad$ Molar fraction of terminal deprotonated amino groups

$X \quad$ Degree of conversion of peptide bonds

\section{INTRODUCTION}

Enzymatic whey protein hydrolysates have found considerable applications in pharmaceutical preparations and in infant nutrition. ${ }^{1,2}$ Most of the beneficial properties of these hydrolysates depend on the length of the peptide chains of the product. $^{3}$ Therefore, the process of hydrolysis has to be carefully controlled in order to obtain a product with the desired properties.

Protein hydrolysis may easily be monitored by means of the $\mathrm{pH}$-stat technique, described originally by Jacobsen et al. ${ }^{4}$ However, the consumption of titrant does not give immediate access to a measure of the degree of hydrolysis and for this reason other methods of analysis have been developed. The degree of hydrolysis can be determined by analysing the increase in the concentration of free $\alpha$-amino groups liberated during hydrolysis. Chemical analyses rely on substances generating chromophores upon reaction with $\alpha$-amino groups, the most commonly used reagents being ninhydrin ${ }^{5}$ and trinitrobenzenesulphonic acid (TNBS). TNBS was introduced by Satake et al. ${ }^{6}$ and the original method has been modified to be suitable for the analysis of partially soluble protein hydrolysates. ${ }^{7}$ These methods, however, demand a lot of sample preparation and tedious procedures. In addition, the criterion of free $\alpha$-amino groups does not correlate precisely with the solubility of the product of protein hydrolysis.

Since in industrial practice the instant solubility of a protein hydrolysate is the most important criterion, the SN-TCA index (the fraction of nitrogen soluble in aqueous trichloroacetic acid under defined conditions) has become a criterion of practical use. This index is also often called nonprotein nitrogen (NPN). The SN-TCA index is a measure of the molar mass distribution of the protein produced. Trichloroacetic acid precipitates essentially all protein molecules and a considerable fraction of the polypeptides. However, as in the case of the titration of liberated $\alpha$-amino groups, the analysis of this index is very demanding and cannot be performed in a continuous manner.

Due to the practical importance of the SN-TCA index and the facility of the $\mathrm{pH}$-stat method it would be interesting to correlate both criteria with one another. It will be shown that a close relationship between these criteria may be established with the $\mathrm{pH}$-stat method which allows a continuous mode of reaction monitoring.

\section{THEORY}

A discussion of the $\mathrm{pH}$-stat method requires knowledge of the phenomena which lead to the production or consumption of protons $\left(\mathrm{H}^{+}\right)$ (synonymously used for hydronium ions $\left(\mathrm{H}_{3} \mathrm{O}^{+}\right)$). A schematic description of the events which occur during protein hydrolysis is given in Fig. 1. The substrate protein of relatively high molar mass

$$
\text { - }
$$

Fig. 1. Schematic representation of protein hydrolysis. 
does not exhibit any appreciable buffer capacity since the amino group of the peptide bonds does not accept a proton in the whole range of $\mathrm{pH}$ from 1 to 14 due to the partial double-bond character of the peptide bond. In addition, the low concentration of terminal amino and carboxyl groups initially present are characterized by $\mathrm{p} K_{\mathrm{a}}$ values of about $3 \cdot 1-3 \cdot 6$ and $7 \cdot 5-7 \cdot 8$, respectively, at $25^{\circ} \mathrm{C}$, whereas the $p K_{n}$ values of the protein side chains deviating only slightly from those of the free amino acids.,8 Protein hydrolysis leads to the liberation of pairs of terminal amino and carboxyl groups exhibiting approximately the same $\mathrm{p} K_{\mathrm{a}}$ values as given above, and which are subject to dissociation equilibria in the aqueous reaction mixture (Fig. 1). Assuming the formation of peptides with charged terminal groups, no change in $\mathrm{pH}$ would be observed since the proton potentially liberated by peptide bond cleavage would stay associated with the amino group. In the $\mathrm{pH}$ range in which the amino group undergoes a dissociation reaction, the formation of a neutral amino group would liberate protons. In contrast, the terminal carboxyl group consumes protons by formation of a neutral species. Therefore, the number of moles of strong acid or base added per mole of peptide bonds cleaved in order to maintain a constant $\mathrm{pH}$ may be given in terms of molar fractions as:

$$
x_{\mathrm{B}}=x_{\mathrm{N}}^{\mathrm{n}}-x_{\mathrm{C}}^{\mathrm{n}}
$$

Assuming a constant mean acid dissociation constant for both terminal groups:

$$
\begin{gathered}
K_{\mathrm{a}}^{\mathrm{N}}=\frac{c_{\mathrm{N}}^{\mathrm{n}} c_{\mathrm{H}}}{c_{\mathrm{N}}^{+}} \text {for: } \mathrm{R}-\mathrm{NH}_{3}^{+} \rightleftharpoons \mathrm{R}-\mathrm{NH}_{2}+\mathrm{H}^{+} \\
K_{\mathrm{a}}^{\mathrm{C}}=\frac{c_{\mathrm{C}}^{-} c_{\mathrm{H}}}{c_{\mathrm{C}}^{\mathrm{n}}} \text { for: } \mathrm{R}-\mathrm{COOH} \rightleftharpoons \mathrm{R}-\mathrm{COO}^{-}+\mathrm{H}^{+}
\end{gathered}
$$

and defining $c_{\mathrm{pb}}^{\mathrm{o}}$ as the total concentration of peptide bonds which may be cleaved and $X$ as the actual fraction of peptide bonds which have been cleaved, the global balance yields:

$$
c_{\mathrm{pb}}^{\mathrm{o}} X=c_{\mathrm{N}}^{\mathrm{n}}+c_{\mathrm{N}}^{+}=c_{\mathrm{C}}^{\mathrm{n}}+c_{\mathrm{C}}^{-}
$$

and

$$
x_{\mathrm{N}}^{\mathrm{n}}+x_{\mathrm{N}}^{+}=x_{\mathrm{C}}^{\mathrm{n}}+x_{\mathrm{C}}^{-}=1
$$

With this, the molar fractions of neutral species may be described as:

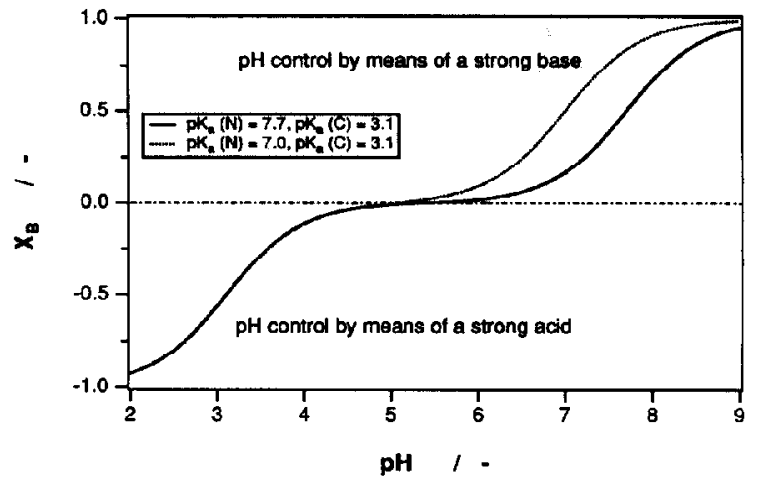

Fig. 2. Titratable fraction of peptide bonds cleaved.

$$
\begin{gathered}
x_{\mathrm{N}}^{\mathrm{n}}=\frac{c_{\mathrm{N}}^{\mathrm{n}}}{c_{\mathrm{pb}}^{\mathrm{o}} X}=\frac{\frac{K_{\mathrm{a}}^{\mathrm{N}}}{c_{\mathrm{H}}}}{1+\frac{K_{\mathrm{a}}^{\mathrm{N}}}{c_{\mathrm{H}}}} \\
x_{\mathrm{C}}^{\mathrm{n}}=\frac{c_{\mathrm{C}}^{\mathrm{n}}}{c_{\mathrm{pb}}^{\mathrm{o}} X}=\frac{1}{1+\frac{K_{\mathrm{a}}^{\mathrm{C}}}{c_{\mathrm{H}}}}
\end{gathered}
$$

With these results and remembering that $\mathrm{pH}=-\log \left(c_{\mathrm{H}}\right)$ and $\mathrm{p} K=-\log (K)$, eqn (1) may be simplified to:

$$
x_{\mathrm{B}}=\frac{1}{1+10^{\left(\mathrm{pK} K^{\mathrm{N}}-\mathrm{pH}\right)}}-\frac{1}{1+10^{(\mathrm{pH}-\mathrm{p} K \mathrm{~A})}}
$$

The function $x_{\mathrm{B}}$, as illustrated in Fig. 2, represents the tritratable fraction of peptide bonds cleaved. A positive sign for $x_{\mathrm{B}}$ indicates that a base has to be added to maintain a constant $\mathrm{pH}$ and a negative sign indicates that an acid has to be added. Since an increase in temperature favours dissociation, the acid exponents of both terminal groups liberated upon protein hydrolysis are expected to be somewhat lower than at $25^{\circ} \mathrm{C}$. Indecd, the acid exponent of the amino group changes from a mean value of 7.7 at $25^{\circ} \mathrm{C}$ to about 7.0 at $55^{\circ} \mathrm{C}$, whereas the acid exponent of the carboxyl group changes only slightly with temperature. ${ }^{3.8}$ Figure 2 also indicates that the final $\mathrm{pH}$ for hydrolyses with a floating $\mathrm{pH}$ should converge at the isoelectric point, that is at a final $\mathrm{pH}$ of about 5.5 at $25^{\circ} \mathrm{C}$ or 5.0 at $55^{\circ} \mathrm{C}$. At the isoelectric point $\mathrm{pl}=\frac{1}{2}\left(\mathrm{p} K_{\mathrm{a}}^{\mathrm{N}}+\right.$ $\mathrm{p} K_{\mathrm{a}}^{\mathrm{C}}$ ) the charges and the degree of protonation of the carboxyl and the amino group balance each 
other $\left(x_{\mathrm{N}}^{\mathrm{n}}=x_{\mathrm{C}}^{\mathrm{n}}\right)$. Hydrolyis at $\mathrm{pH}=\mathrm{pl}$, therefore, does not lead to a change in $\mathrm{pH}$.

By definition, the degree of conversion $(X)$ used above is identical with the degree of hydrolysis (DH) defined by Adler-Nissen. ${ }^{3,9}$ Re-defining the tritatable fraction $x_{B}$ in terms of observable variables yields:

$$
x_{\mathrm{B}}=\frac{V_{\mathrm{B}} c_{\mathrm{B}}}{V_{\mathrm{R}} c_{\mathrm{pb}}^{\mathrm{a}} X}=x_{\mathrm{N}}^{\mathrm{n}}-x_{\mathrm{C}}^{\mathrm{n}}
$$

The degree of hydrolysis may be correlated with the volumetric consumption of strong acid or base:

$$
\mathrm{DH}=X=\frac{1}{x_{\mathrm{N}}^{\mathrm{n}}-x_{\mathrm{C}}^{\mathrm{n}}} \frac{V_{\mathrm{B}} c_{\mathrm{B}}}{V_{\mathrm{R}} c_{\mathrm{pb}}^{\mathrm{o}}}
$$

A negative sign in eqn (9) again simply states that a strong acid has to be used for $\mathrm{pH}$ control. Equation (9) also indicates that the $\mathrm{pH}$-stat method cannot be applied in the range of the isoelectric point - as discussed above. The number of moles of peptide bonds present in a reactor may be estimated from:

$$
n_{\mathrm{pb}}^{\mathrm{o}}=V_{\mathrm{R}} c_{\mathrm{pb}}^{\mathrm{o}}=\frac{m_{\mathrm{P}}^{\mathrm{o}}}{M_{\mathrm{pb}}}
$$

with the mean equivalent molar mass associated with a cleavable peptide bond $\left(M_{\mathrm{pb}}\right)$ of $113.6 \mathrm{~g}$ $\mathrm{mol}^{-1}$ for whey proteins. ${ }^{3}$

In the case of limited protein hydrolysis a fairly linear relationship is found for correlating the degree of hydrolysis with base consumption. ${ }^{3}$ This must not necessarily be the same for the relationship between the SN-TCA index and base consumption. The solubility may increase rapidly at low protein conversion, whereas at high conversion solubility may only change slowly due to the splitting of soluble peptides.

\section{MATERIALS AND METHODS}

Partially demineralized whey protein concentrate (WPC) with an average protein content of $22 \%$ (w/w) was employed as substrate. Hydrolysis was achieved with a commercial enzyme preparation of porcine pancreatic trypsin, PTN 6.0 S (Novo Nordisk, Denmark). Active site titration with $p$ nitrophenyl guanidinobenzoate according to the method of Chase and Shaw ${ }^{10}$ yielded a concentra- tion of active enzyme of $10 \cdot 2 \mu \mathrm{mol} \mathrm{g}^{-1}$ for this preparation.

All experiments were performed at a substrate concentration of $20 \%(w / w)$ WPC. Prior to starting the reaction, trypsin was solubilized in $1 \mathrm{~mm}$ $\mathrm{HCl}$ containing $5 \mathrm{~mm} \mathrm{CaCl}_{2}$. The reaction was carried out in a jacketed stirred tank reactor, with a volume of $100 \mathrm{ml}$, at a constant temperature of either 55 or $60^{\circ} \mathrm{C}$. The reactor was operated discontinuously. A small mechanical stirrer was operated at $1000 \mathrm{rev} \mathrm{min}-1$. The installation was equipped with a pH-meter (Metrohm 632, Switzerland) and a titrator-controller unit (Metrohm 614), enabling the reaction mixture to be maintained at a constant $\mathrm{pH}$ of $7 \cdot 3$ by feeding a $4 \mathrm{~N}$ $\mathrm{KOH}$ solution with an auto-burette (Metrohm 535). The volume of strong base added during the reaction was recorded on a PC equipped with a data acquisition board. The protein solution was treated for $5 \mathrm{~min}$ at $90^{\circ} \mathrm{C}$ prior to starting the reaction by addition of the enzyme. The total time required for this treatment at $90^{\circ} \mathrm{C}$ was about 13-14 min.

The SN-TCA index is expressed in terms of the fraction of soluble nitrogen (NPN: 'non-protein nitrogen'). The SN-TCA index was evaluated by treating samples of the reaction mixture with an aqueous solution of $13.6 \%(w / w)$ trichloroacetic acid. For the analysis of the NPN, both the original sample of the reactor contents and a sample of the supernatant after TCA treatment and centrifugation were analysed by the Kjeldahl method. The Kjeldahl digestion was carried out in a Büchi 402 rapid digestion unit (Flawil, $\mathrm{CH}$ ) and a distillation unit (Büchi 322) equipped with an automatic control unit for titration (Büchi 343). The NPN values were calculated by dividing the soluble nitrogen concentration by the total nitrogen concentration.

\section{RESULTS AND DISCUSSION}

Figure 3 shows an example of a discontinuous reaction without $\mathrm{pH}$ control. The drop in $\mathrm{pH}$ is rather steep due to the poor buffering capacity of the proteins, followed by a slow descent at low $\mathrm{pH}$. This slow descent may be explained both by the approach of the isoelectric point of the terminal groups liberated and by the low activity of trypsin in this range of $\mathrm{pH}$.

The correspondence of the degree of protein hydrolysis expressed in terms of NPN and the 


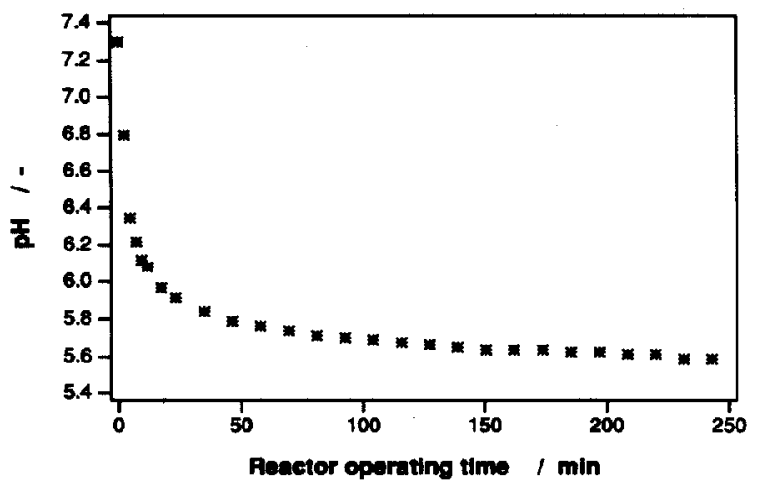

Fig. 3. An example of protein hydrolysis without $\mathbf{p H}$ control $\left(T_{\mathrm{c}}=55^{\circ} \mathrm{C}, S_{\mathrm{o}}=20 \%(\mathrm{w} / \mathrm{w}), E_{\mathrm{o}} / S_{\mathrm{o}}=0.01\right)$.

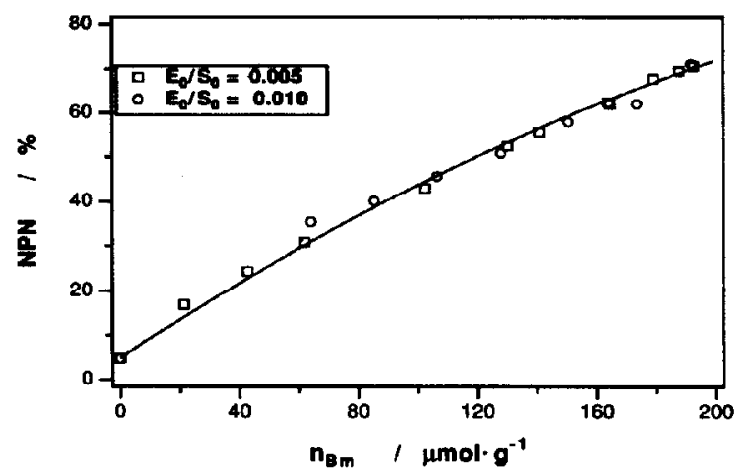

Fig. 4. Correlation of the soluble protein fraction expressed as NPN and the amount of strong base consumed per unit mass of protein $\left(T_{c}=55^{\circ} \mathrm{C}, S_{0}=20 \%(w / w)\right.$, $\mathbf{p H}=7 \cdot 3$ ).

mass-specific base consumption is given in Figs 4 and 5 for reaction temperatures of 55 and $60^{\circ} \mathrm{C}$, respectively. These correlations were established at two different enzyme-substrate ratios.

The dependence of NPN on base consumption may conveniently be expressed in the form of polynomials:

$$
\mathrm{NPN}-\mathrm{NPN}_{0}=a_{1} n_{\mathrm{Bm}}-a_{2} n_{\mathrm{Bm}}^{2}
$$

with

$$
n_{\mathrm{Bm}}=\frac{1}{m_{\mathrm{P}}^{\mathrm{o}}} V_{\mathrm{B}} c_{\mathrm{B}}=\frac{n_{\mathrm{B}}}{m_{\mathrm{P}}^{\mathrm{o}}} \quad\left(\mu \mathrm{mol} \mathrm{g}^{-1}\right)
$$

where $\mathrm{NPN}_{\mathrm{o}}$ is the initial non-protein nitrogen fraction of the whey protein concentrate. The WPC employed had an initial NPN of $4.8 \%$. The coefficients of the correlations are gathered in Table 1 for both reaction temperatures of 55 and

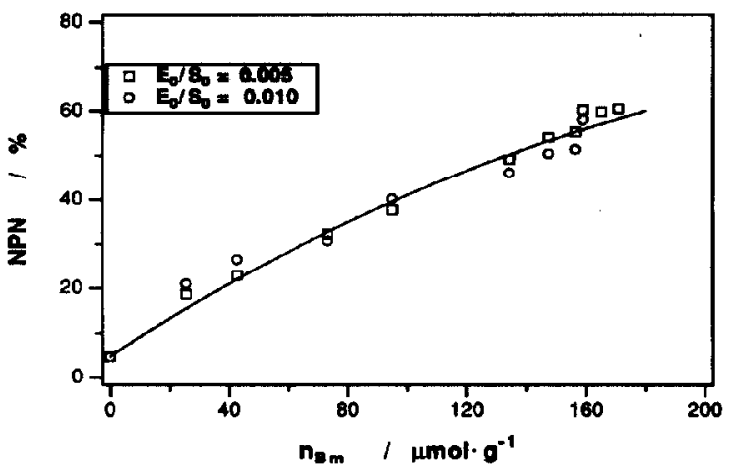

Fig. 5. Correlation of the soluble protein fraction expressed as NPN and the amount of strong base consumed per unit mass of protein $\left(T_{c}=60^{\circ} \mathrm{C}, S_{\mathrm{o}}=20 \%(\mathrm{w} / \mathrm{w})\right.$, $\mathrm{pH}=7 \cdot 3$ ).

Table 1. Regression coefficients for the correlation of NPN and base consumption

\begin{tabular}{ccc}
\hline $\begin{array}{c}\text { Temperature } \\
\left({ }^{\circ} \mathrm{C}\right)\end{array}$ & $\begin{array}{c}a_{1} \\
\left(\% \mathrm{gmol} \mathrm{m}^{-1}\right)\end{array}$ & $\begin{array}{c}\mathrm{a}_{2} \\
\left(\% \mathrm{~g}^{2} \mu \mathrm{mol}^{-2}\right)\end{array}$ \\
\hline 55 & 0.44 & $-0.524 \times 10^{-3}$ \\
60 & 0.42 & $-0.584 \times 10^{-3}$ \\
\hline
\end{tabular}

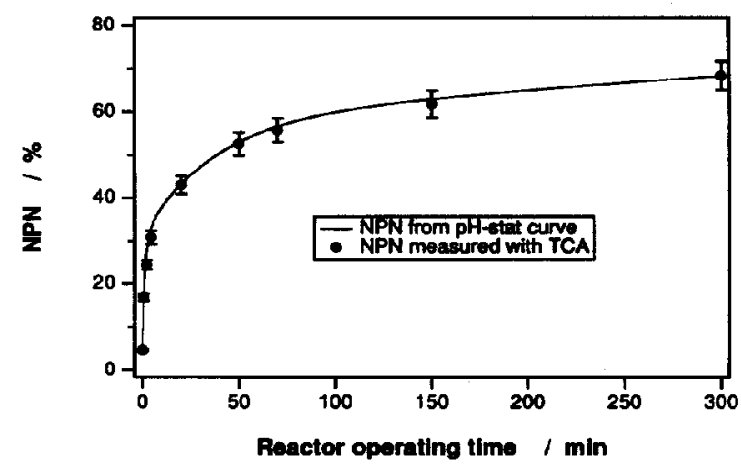

Fig. 6. Discontinuous hydrolysis reaction for testing the correlation between NPN and base consumption $\left(T_{\mathrm{c}}=55^{\circ} \mathrm{C}\right.$, $\left.S_{\mathrm{o}}=20 \%(\mathrm{w} / \mathrm{w}), E_{\mathrm{o}} / S_{0}=0 \cdot 005, \mathrm{pH}=7 \cdot 3\right)$.

$60^{\circ} \mathrm{C}$. As expected, the correlation between the soluble nitrogen content and the quality of base added per unit mass of whey protein is not linear because, as discussed earlier, the concentration of soluble peptides formed cannot be expected to be a linear function of peptide bonds cleaved.

An independent measurement at an operating temperature of $55^{\circ} \mathrm{C}$ is given in Fig. 6. Equation (11) together with the coefficients of Table 1 have been used for calculating the fraction of soluble 
protein (shown as a continuous line in Fig. 6). Some parallel analyses of the fraction of soluble protein by means of the TCA method indicate a close agreement of both results.

\section{CONCLUSION}

The SN-TCA index, a criterion of practical importance for characterizing protein hydrolysates, has been correlated with the amount of base added for $\mathrm{pH}$ control. This allows the simple $\mathrm{pH}-$ stat procedure to be used for continuous monitoring of the degree of reaction. Thus, once calibrated under different reaction conditions, data about the reaction system may be readily obtained. ${ }^{11}$ This method may be applied not only in this particular case, but also for analysing the hydrolysis of other proteins by means of other proteases, unless the $\mathrm{pH}$ optimum of the enzyme falls into the range of the isoelectric point of the dissociating groups liberated during hydrolysis.

\section{REFERENCES}

1. Evans, E. W., Uses of milk proteins in formulated foods. In Developments in Food Proteins, Vol. 1, ed. B. J. F.
Hudson. Applied Science Publishers, London and New York, 1985, pp. 131-69.

2. Jost, R., Monti, J. C. \& Pahud, J. J., Whey protein allergenicity and its reduction by technological means. Food Technol., 41 (10) (1987) 118-21.

3. Adler-Nissen, J., Enzymic Hydrolysis of Food Proteins. Elsevier Applied Science Publishers, London and New York, 1986.

4. Jacobsen, C. F., Léonis, J., Linderström-Lang, K. \& Ottesen, M., The pH-stat and its use in biochemistry. Meth. Biochem. Anal., 4 (1957) 171-210.

5. Moore, S. \& Stein, W., A modified ninhydrin reagent for the photometric determination of amino acids and related compounds. J. Biol. Chem., 211 (1954) 907-13.

6. Satake, K., Okuyama, T., Ohashi, M. \& Shinoda, T., The spectrophotometric determination of amine, amino acid and peptide with 2,4,6-trinitrobenzene 1-sulfonic acid. J. Biochem., 47 (5) (1960) 654-60.

7. Adler-Nissen, J., Determination of degree of hydrolysis of food protein hydrolysates by trinitrobenzenesulfonic acid. J. Agric. Food Chem., 27 (6) (1979) 1256-62.

8. Steinhardt, J. \& Beychok, S., Interaction of proteins with hydrogen ions and small ions and molecules. In The Proteins, Vol. II, 2nd end, ed. H. Neurath. Acadcmic Press, New York, 1964, pp. 139-304.

9. Adler-Nissen, J., Enzymatic hydrolysis of food proteins. Process Biochem., 12 (6) (1977) 18-23, 32.

10. Chase, T. \& Shaw, E., Titration of trypsin, plasmin and thrombin with $p$-nitrophenyl $p^{\prime}$-guanidinobenzoate $\mathbf{H C l}$. Meth. Enzymol., 19 (1970) 20-7.

11. Margot, A., Développement d'un réacteur continu pour l'hydrolyse enzymatique de protéines du lactosérum. PhD thesis No. 994, Swiss Federal Institute of Technology, Lausanne, 1992. 